\title{
Angiographic appearance of a cerebral aneurysm rupture
}

自

Supplemental data at Neurology.org
A 53-year-old woman was referred because a CT scan disclosed a subarachnoid hemorrhage. An aneurysm was seen on digital subtraction angiography, which suddenly ruptured (video 1 on the Neurology ${ }^{\circledR}$ Web site at Neurology.org) during the study, suggesting the cause of the hemorrhage (video 2). The rate of contrast emission was $3 \mathrm{~mL} / \mathrm{s}$ with a total volume of $16 \mathrm{~mL}$; the pressure was 200 psi. External ventricular drainage was performed emergently, and the patient was transferred to the intensive care unit. She recovered uneventfully after the aneurysm clipping.

Changwei Zhang, $M D,{ }^{*}$ Ding Xu, MD, * Shouwei Xiang, MD, Chao You, MD, Xiaodong Xie, MD

*These authors contributed equally to this work and should be considered as co-first authors.

From West China Hospital, Sichuan University, China.

Author contributions: All authors were involved in clinical care and investigative workup of the patient. Changwei Zhang and Ding Xu provided video of the patient and drafted and revised the manuscript. Shouwei Xiang performed the patient follow-up. Xiaodong Xie and Chao You were responsible for the study concept, performed the craniotomy surgery after the aneurysm rupture, and revised the manuscript for intellectual content.

Study funding: No targeted funding reported.

Disclosure: The authors report no disclosures relevant to the manuscript. Go to Neurology.org for full disclosures.

Correspondence to Dr. Xie: xiexiaodongwsh@163.com

\section{We Value Diversity! Applications Open for 2016 AAN Diversity Leadership Program}

Applications are open for the 2016 American Academy of Neurology Diversity Leadership Program, a unique opportunity designed to identify, orient, and cultivate AAN members from diverse and underrepresented ethnic backgrounds who have strong potential for developing into future leaders. Space is limited and applications are required. Visit AAN.com/view/DiversityLeadershipProgram to learn more and to apply by the January 7, 2016, deadline.

\section{Experience the Excellence of the 2016 AAN Annual Meeting}

Registration is now open for the $68^{\text {th }}$ AAN Annual Meeting, set to take place Friday, April 15, through Thursday, April 21, 2016, at the Vancouver Convention Centre in Vancouver, BC, Canada. Experience the excellence of new, exciting changes, including: one low, single registration rate; more than 230 education programs in two-hour increments; plenary sessions every day starting Friday; scientific poster sessions every day starting Saturday; interactive and experiential learning and networking opportunities all week long, and more! The money-saving early registration deadline is March 24, 2016. Visit AAN.com/view/AM16 and register today! 


\section{Neurology}

\section{Angiographic appearance of a cerebral aneurysm rupture}

Changwei Zhang, Ding Xu, Shouwei Xiang, et al.

Neurology 2015;85;1821

DOI 10.1212/WNL.0000000000002134

This information is current as of November 16, 2015

$\begin{aligned} & \text { Updated Information \& } \\ & \text { Services }\end{aligned}$
Supplementary Material
Subspecialty Collections

Subspecialty Collections

Permissions \& Licensing

Reprints including high resolution figures, can be found at:

http://n.neurology.org/content/85/20/1821.full

Supplementary material can be found at:

http://n.neurology.org/content/suppl/2015/11/14/WNL.0000000000002 134.DC1

This article, along with others on similar topics, appears in the following collection(s):

Clinical neurology examination

http://n.neurology.org/cgi/collection/clinical_neurology_examination

Critical care

http://n.neurology.org/cgi/collection/critical_care

Intracerebral hemorrhage

http://n.neurology.org/cgi/collection/intracerebral_hemorrhage

Methods of education

http://n.neurology.org/cgi/collection/methods_of_education

Subarachnoid hemorrhage

http://n.neurology.org/cgi/collection/subarachnoid_hemorrhage

Information about reproducing this article in parts (figures,tables) or in its entirety can be found online at:

http://www.neurology.org/about/about_the_journal\#permissions

Information about ordering reprints can be found online:

http://n.neurology.org/subscribers/advertise

Neurology ${ }^{\circledR}$ is the official journal of the American Academy of Neurology. Published continuously since 1951, it is now a weekly with 48 issues per year. Copyright () 2015 American Academy of Neurology. All rights reserved. Print ISSN: 0028-3878. Online ISSN: 1526-632X.

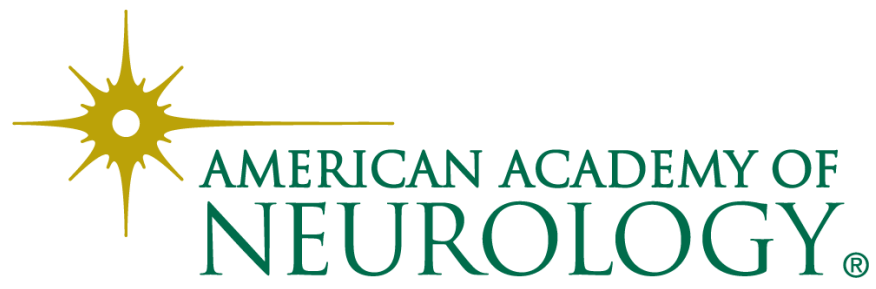

